\title{
EPISTEMOLOGIAS BRAUDELIANAS: ESPAÇO, TEMPO E SOCIEDADE NA CONSTRUÇÃO DA GEO-HISTÓRIA
}

\author{
GUILHERME RIBEIRO* \\ Universidade Veiga de Almeida - Cabo Frio (RJ)
}

"Epistemologias", embora trate-se de um único pensamento. "Braudelianas", embora trate-se de um único autor. No entanto, o que transborda quando da leitura da obra do historiador francês Fernand Braudel (1902-1985) é exatamente a pluralidade de seus escritos, de suas reflexões, de suas idéias. Multiplicidade que caminha no sentido de uma profunda coerência interna, tal como aponta um de seus principais estudiosos, o mexicano Carlos Antonio Aguirre Rojas (ROJAS, 2003a). Dialética entre um pensamento singular e idéias no plural, dialética também entre a Geografia e a História, tema central destas breves linhas. Passados 21 anos após sua morte, vivemos uma conjuntura fortemente propícia para aqueles que se interessam pela crítica às fronteiras disciplinares, por uma abordagem focada na totalidade, pela preocupação com temas de dimensões globais e pela inteligibilidade do conhecimento em Ciências Humanas, na medida em que uma onda de irracionalismo, pessimismo e conformismo insiste em nos cercar.

Entretanto, posições extremadas à parte, o que se tem chamado genericamente de pós-modernidade nos faz repensar e rever determinados pontos-de-vista acerca da construção do conhecimento, dos métodos e de seus resultados em Ciências Humanas, o que certamente só pode ser visto de maneira positiva. Crer que seja necessário sair "em defesa da História" (WOOD \& FOSTER, 1999) ou que a História-disciplina esteja em vias de destruição (MOURA, 2000) talvez seja o

\footnotetext{
* Doutorando em Geografia pela Universidade Federal Fluminense (UFF) e professor de Teorias da História do curso de Licenciatura em História da Universidade Veiga de Almeida, campus Cabo Frio (RJ). O autor agradece a Manoel Fernandes (UFC) e, sobretudo, a Sergio Nunes (UFF), pelos sugestivos comentários sobre este texto.
} 
caminho mais rápido para perdermos a oportunidade de, efetivamente, promover um amplo debate entre os campos científicos então existentes.

Este é o contexto que nos envolve e nos impele a escrever sobre a Geografia em Fernand Braudel que, à sua maneira, desejou ser o arquiteto de uma grande empreitada. Nesse sentido, a proposta que se apresenta é a de reunir, mediados pela Epistemologia, procedimentos da Historiografia e da história do Pensamento Geográfico ou, em outras palavras, averiguar o papel epistemológico da Geografia na obra de Braudel a partir de suas relações com a historiografia de seu tempo e de seus diálogos com a ciência geográfica.

\section{Os Annales, a Escola Francesa de Geografia e as Ciências Humanas no limiar do século $\mathrm{XX}$}

O final do século XIX e o início do século XX são, em França, momentos importantes no processo de institucionalização das Ciências Humanas, que se apresentam como um dado novo na ordem do saber (FOUCAULT, 1999). Tendo a Alemanha como modelo, ao creditar a derrota na guerra franco-prussiana (187071) aos avanços científicos do rival, os franceses se dedicam a desenvolver uma ciência marcadamente nacionalista, tal como atestam os escritos de Langlois, Seignobos e Lavisse, no campo da História, e os de Vidal de la Blache na Geografia. À primeira cabia a construção de um passado glorioso e que pudesse ser motivo de orgulho para um povo ferido (DOSSE, 2001), enquanto à segunda reservou-se o papel de formar cidadãos e fortificar seu patriotismo, bem como o ensino de mapas e o conhecimento das regiões francesas ' (LACOSTE, 1988). Acrescentemos a este quadro que na França a Faculdade de Letras proporcionava uma dupla formação, na qual, só com o passar dos anos, o diplomado optava por tornar-se historiador ou geógrafo. Havia, portanto, um fértil campo de possibilidades ${ }^{2}$.

No entanto, tudo indica que seria necessário esperar a crítica formulada a uma História positivista, tradicional, factual, narrativa, biográfica, militar, centrada no Estado e em suas guerras, nos grandes acontecimentos, para que a articulação entre a Geografia e a História sofresse uma modificação significativa. Estamos nos referindo aos Annales, tidos pelo historiador inglês Peter Burke como a "Revolução

\footnotetext{
' O que não impediu que a Alemanha continuasse a exercer influência entre os historiadores e geógrafos franceses, sendo essencial a presença de Ranke, Ritter e Ratzel em suas respectivas formações, conforme destaca Berdoulay sobretudo no capitulo I, intitulado "O desafio alemão" (BERDOULAY, 1981:17-43).

${ }^{2}$ Exemplos conhecidos desta situação são os de Paul Vidal de La Blache, formado historiador porém geógrafo consagrado, e Georges Duby e Pierre Vilar, formados geógrafos mas consagrados enquanto historiadores
} 
Francesa" da Historiografia, dado o impacto desta corrente na forma de se escrever e fazer a ciência histórica. Uma História-problema, comparativa, global interdisciplinar, aberta à sociedade, à cultura, às mentalidades, à economia, utilizandose dos mais variados tipos de fontes ${ }^{3}$.

Nestas trocas entre Febvre, Bloch e os demais cientistas sociais da época no seio do processo de formação dos Annales, certamente a Geografia possui papel de destaque. De acordo com o historiador brasileiro José Carlos Reis, os Annales são um projeto "do exterior da História", cujas fontes principais seriam a crítica histórica de François Simiand e de Henri Berr, a Sociologia Durkheimiana e a Geografia Humana de Vidal (REIS, 2000:52-63). Bloch retrata as paisagens dos campos, das aldeias e dos bosques como marcas deixadas pelas comunidades agrárias francesas e escreve um estudo de caráter monográfico sobre a região da Ille-de-France (BLOCH, 2001), assim como o faz Febvre quando de sua tese de doutorado sobre a Franche-Comté (FEBVRE, 1970). Os dois escreveriam vários artigos de história regional publicados na Revue de Synthèse Historique, onde Febvre era o supervisor deste setor. Aliás, ele é explícito ao afirmar que "Na realidade, poderíamos dizer que em certa medida foi a Geografia que engendrou a História que adotamos" (FEBVRE, 1954, apud DAIX, 1999:62), merecendo por isto a reprovação do historiador brasileiro Ciro Cardoso, que considera a assertiva "sem dúvida um exagero" (CARDOSO, 2005:144).

Exagero ou não, o amigo pessoal de Braudel publicaria também no ano de 1922 A Terra e a Evolução Humana: introdução geográfica à História, livro-chave no entendimento das relações entre geógrafos e historiadores na França na primeira metade do século XX e que se apresenta como um verdadeiro manual metodológico acerca da importância geográfica em História (FEBVRE, 1991), bem como uma obra sobre o rio Reno, escrita em parceria com o geógrafo Albert Demangeon ${ }^{4}$ (FEBVRE e DEMANGEON, 1935). Dando seqüência ao legado dos fundadores dos Annales, em 1946, no prólogo da primeira edição francesa de $O$ Mediterrâneo e o mundo mediterrâneo à época de Felipe II, numa referência explícita à Escola Metódica, ainda se mostrava descontente com aquelas tradicionais e rápidas introduções geográficas à História que simplesmente desapareciam no decorrer da exposição (BRAUDEL, 2002). Não custa lembrar que, durante o período em que

\footnotetext{
${ }^{3}$ Não nos deteremos pormenorizadamente acerca do surgimento da revista Annales d'histoire économique et sociale fundada em 1929 pelos historiadores Lucien Febvre e Marc Bloch, originando o que conhecemos como "Escola" dos Annales. Já existe uma bibliografia considerável em torno do assunto (DOSSE, 1992; REIS, 1994, 2000; ROJAS, 2000, 2004; BURKE, 1997; GURIÊVITCH, 2003; FONTANA, 1998, 2004), cabendo aqui somente assinalar alguns aspectos desta corrente dentro dos objetivos do presente texto.

${ }^{4}$ Demangeon também foi um dos co-editores dos Annales d'histoire économique et sociale, traço sintomático da aproximação Geografia-História na França do início do século XX.
} 
esteve cativo dos alemães durante a II Guerra Mundial, em uma constante troca de correspondências com Febvre, Braudel recebe um conselho para que invertesse $o$ título - e, conseqüentemente, o tema - de sua tese, que seria apenas mais uma obra tradicional sobre a política diplomática de Felipe II no século XVI (PARIS, 1999), transformando assim um mar em objeto da História, geografizando o conhecimento e a pesquisa histórica.

Como era a Geografia que atraía tamanha atenção da História nesta virada do século XIX para o século XX? Um campo de saber marcado pelo empirismo e objetividade fornecidos por intermédio dos trabalhos de campo e pela linguagem cartográfica, estudando as relações homem-meio focalizadas, sobretudo, na escala regional. "A França que se chama diversidade", escreverá Braudel já no final da vida, repetindo as palavras de seu mestre Febvre e acertando as contas com sua terra natal. Uma França composta por diferentes regiões que, aos poucos, foram se unindo política e territorialmente por este enorme gestor moderno chamado Estado Nacional (BRAUDEL, 1989). Identidade da França, identidade da Geografia, esta sendo construída a partir das variadas paisagens lentamente formadas e modificadas pelas sociedades em sua transformação permanente da natureza. Por trás destes tópicos, emerge a figura de Paul Vidal de La Blache, nome maior da Geografia francesa que ocupa os principais postos institucionais deste país contribuindo na difusão do conhecimento geográfico em escala nacional - apoiando, neste sentido, a colonialização, "à qual a nossa época ligou a sua glória" (VIDAL DE LA BLACHE, 1954). Personagem deveras complexo, em 1891 funda os Annales de Géographie, que inspirariam os futuros Annales dos historiadores, divulgando um campo de saber diferente do "ideal de contemplação" que caracterizava os trabalhos dos alemães Carl Ritter e Alexander von Humboldt no século XIX (GOMES, 1997:14). Entrava em cena uma Geografia de cunho científico que se propunha a investigar a ação humana sobre a superfície terrestre. Mas, não terá sido, talvez, o projeto mais difícil de ser realizado dentre a operação de seleção dos objetos levada adiante pelas Ciências Humanas? Ao integrar o Homem, a Natureza e a Cultura, não estaria a Geografia dando um passo vanguardista demais precisamente em um momento de delimitação dos saberes?

Um pouco nesta linha de raciocínio segue (não como uma interrogação, mas como uma afirmação inequívoca) Lucien Febvre, alinhando-se aos sociólogos durkheimianos em suas críticas endereçadas ao geógrafo alemão Friedrich Ratzel. Partidários da moderna divisão do trabalho acadêmico, enquadrando certos temas a disciplinas específicas e esforçando-se em delimitar "cientificamente" os objetos de cada campo do conhecimento, Febvre interpreta a tentativa de Ratzel de estudar todas as influências que o solo pode exercer sobre a vida social em geral como "quimérica", uma verdadeira "pilhagem audaciosa em domínios reservados", fazendo com que a Geografia desaparecesse enquanto "ciência distinta". À aproximação ratzeliana com a Antropologia, Febvre dirá ser "preconceito de 
antropogeógrafo", e ao seu interesse pelas questões relativas ao Estado e o território, "preocupações de ordem mais política que científica", admitindo ainda que seu livro Politische Geographie é "uma espécie de manual do imperialismo alemão" (FEBVRE, 1991:45-46).

Há, certamente, várias ordens de problemas em torno destas questões, forçosamente resumidas e apresentadas somente de passagem ${ }^{5}$. São elas: (i) a simplificação do pensamento de Ratzel; (ii) a apropriação pelos Annales da Geografia Humana de Vidal; (iii) o "imperialismo" da História praticâda pelos Annales; (iv) a fragmentação entre as ciências vigente no âmbito da Modernidade.

Quanto ao primeiro tópico, o geógrafo brasileiro Marcos de Carvalho, empenhado em resgatar criticamente a herança de Ratzel, ressalta que ele é lembrado apenas por seu determinismo e por suas idéias acerca da expansão dos Estados, ou seja, apenas por uma parte de sua reflexão, deslocando a complexidade multidisciplinar de seu pensamento em benefício da afirmação de identidades corporativas (CARVALHO, 1997, 1997a). Não devemos esquecer também da lembrança da guerra franco-prussiana e do ambiente belicoso causado pela I Guerra Mundial, afetando diretamente a França. No que tange à organização do ambiente acadêmico neste país, buscou-se construir uma ciência com raízes efetivamente nacionais, afastada dos modelos alemães hegemônicos até então.

No tocante ao segundo ponto, a leitura feita pelos historiadores dos Annales (sobretudo por Febvre) da Geografia vidaliana negligencia a dimensão politica da mesma, focalizando apenas aquilo que os interessava na esfera do projeto interdisciplinar por eles praticado. Segundo Lacoste - ao que tudo indica o pioneiro nesse debate - Febvre negligenciou justamente o livro que trata do "pertencimento" da Alsácia e da Lorena ao corpo nacional francês, intitulado A França do Leste (VIDAL DE LA BLACHE, 1994). A reflexão geopolítica nele contida aproximaria Vidal de Ratzel, seria incompatível com o deslocamento da História Política para a História Econômica e Social operado pelos Annales e não se encaixaria no manual de Geografia preconizado por Febvre, no qual haveria uma geografia política, mas desde que estreitamente solidária da geografia humana (FEBVRE, 1991). Os olhos do historiador estavam voltados especialmente para a relação homem-meio - como se, inocentemente, a forma pela qual as sociedades lidam com o ambiente pudesse ser desprovida e desvinculada de uma conotação política (LACOSTE, 1988).

Vislumbrava Febvre uma unidade do conhecimento sem limites rigidamente estipulados, como desejam alguns? (cf. MOTA, 1994:15). Era muito conveniente para a História dialogar com a Geografia desta maneira, posto que as posições de cada uma, o status das mesmas no seio da comunidade acadêmica em nada abalava

\footnotetext{
' O leitor deverá consultar, especialmente, o capítulo intitulado Morfologia Social ou Geografia Humana, dentro da parte primeira denominada, sugestivamente, Como formular o problema. A. Questão do Método (FEBVRE, 1991:45-72).
} 
aquela, pelo contrário. Já não foram os Annales acusados de academicismo? (REIS, 2000:180).

Articulado diretamente com esta problemática está o "imperialismo" dos Annales, alçando a ciência histórica ao patamar mais elevado entre as Ciências Humanas. Mesmo que os Annales tenham avançado sobremaneira no diálogo com as demais disciplinas sociais, alargando consideravelmente o campo de atuação histórico, em seus escritos os limites entre os campos do conhecimento continuavam visíveis e presentes, com a legitimidade e a especificidade da História dadas a partir de sua diferença em relação às demais ciências. Não é esta a arquitetura dita interdisciplinar desenhada por Braudel, admitindo na longa duração temporal a linguagem comum entre as Ciências do Homem? (BRAUDEL, 1969). Lacoste chega a dizer que Febvre "impossibilitou qualquer reflexão geopolítica aos geógrafos... para reserválas aos historiadores ávidos de geo-história!" (1988:123). Neste caso, tratar-se-ia de uma denúncia apropriada ou de um corporativismo raivoso?

Por fim, estes três aspectos situam-se no bojo de um amplo movimento de fragmentação do conhecimento em campos científicos, pondo fim aos grandes esquemas explicativos e sintéticos que marcaram o século XIX, como o Marxismo, o Positivismo e o Hegelianismo. Em termos Foucaultianos, inaugurava-se a episteme moderna, onde cada ciência possuiria objeto, vocabulário e metodologia próprios, afastando-se progressivamente umas das outras e representando um único mundo de variadas formas. Tal quadro torna-se mais complexo com a crise do paradigma cartesiano-newtoniano (que visava a unificação das ciências via matemática, leis e experimentação), tornada patente com o aparecimento do Homem como um dado novo na ordem do saber pelas Ciências Humanas (FOUCAULT, 1999). O HomemObjeto do Sujeito-cientista, uma novidade que nos remete a um impasse ontoepistemológico: a difícil fratura, mesmo no campo do pensamento científico - ou seja, mesmo em um ambiente de operações simbólicas e instáveis onde aparentemente, ou melhor, Racionalmente, tudo é possível -, do Homem enquanto Ser. O Homem-Ser que vive em sociedade mas que demora a constituir-se enquanto Sociologia; o Homem-Ser que vive espacialmente e grafa suas marcas na paisagem, mas que demora a constituir-se enquanto Geografia; o Homem-Ser temporal, mutável e dinâmico, que carrega consigo as consequências de seus atos e de sua memória, mas que demora a constituir-se enquanto História; o Homem-Ser que pratica certos atos e se comporta de maneiras diferentes, mas que demora a constituir-se enquanto Antropologia.

Enfim, as novas explorações realizadas pelos Annales teriam como um de seus principais traços a ênfase dada às relações homem-meio, o reconhecimento da mudança e da permanência dos aspectos que compunham a paisagem de um determinado lugar, identificando a constituição física da mesma aliada ao comportamento social e cultural de seus habitantes. Portanto, não apenas a dimensão temporal era posta em destaque, tal como acontecia habitualmente. Neste panorama, o conjunto das obras de Marc Bloch, Lucien Febvre e Fernand Braudel levanta e 
problematiza algo já conhecido pelos historiadores, mas com uma abordagem deveras original. Para eles, as sociedades estão diretamente associadas a um determinado espaço, grafando seus traços numa paisagem cujas formas correspondem e representam um dado período histórico, com todo este movimento podendo ser circunscrito a várias escalas (local, regional e nacional) e apreendido através da longa duração. Destarte, o espaço, a paisagem, a região e o território passam a constituir-se em objetos passíveis de serem pesquisados pelos historiadores, posto que seu conteúdo e sua construção são transformados e modificados pelo Homem $3 / 4$ a "caça" do historiador, aquilo que justifica a intervenção da História dentre os demais campos do conhecimento (BLOCH, 2001:54). O meio deixa de ser uma fatalidade e o historiador passa a atentar tanto para a modificação dos traços à primeira vista imutáveis quanto para a ação humana exercida no meio. Na concepção dos Annales, a História é, também, geográfica, e aqueles que se dedicam à compreensão desta corrente historiográfica, independente de estarem filiados à mesma, são unânimes em afirmar este vínculo.

Entretanto, a influência da Geografia na gênese dos Annales, nos textos publicados na revista e também em termos individuais, ou seja, nos trabalhos de Febvre, Bloch e Braudel é, ao nosso ver, um tema pouco estudado. Tudo indica que os geógrafos não têm tido interesse pelo tema (em virtude de um certo desdém em relação à sua própria história?); do lado dos historiadores, nota-se um maior interesse pela influência exercida por Berr, Simiand e Durkheim - embora, quando se trate de Braudel, as coisas avancem um pouco em ambas direções (LACOSTE, 1989; HAESBAERT, 1993; ARAÚJO, 2004; CLAVAL, 1980; ROJAS, 2000, 2003, 2003a; REIS, 1994; LLOYD, 1995). Pierre Daix, p.ex., admite um estranho receio de que tenha superestimado "os problemas da Geografia na formação e no desenvolvimento do historiador Braudel", embora admita que, na verdade, ele e Braudel fizeram parte de uma geração que valorizava a Geografia, enquanto atualmente esta é relegada na formação dos jovens historiadores (DAIX, 1999:15). Em recente coletânea publicada em português e dedicada exclusivamente a Braudel, dos doze artigos disponíveis nenhum se dispôs a desenvolver a questão supracitada (LOPES, 2003).

\section{A Geografia e a escrita histórica braudeliana}

Até aqui, estamos diante de duas questões proeminentes recebidas como herança por Fernand Braudel: a decisiva influência da Geografia na constituição dos Annales e a progressiva e evidente diferenciação entre as Ciências Humanas, elementos estes que, para os objetivos desta investigação, marcam significativamente a primeira metade do século XX. Entretanto, o que distingue a perspectiva geográfica braudeliana das abordagens anteriores? No conjunto de sua obra, porque a Geó- 
História assume tamanho destaque, a ponto de afirmarmos que ela representa um ponto de convergência epistemológico entre estas duas ciências? Ao que tudo indica, Braudel leva o compromisso com a Geografia às últimas consequências: desde seu primeiro grande trabalho - Mediterrâneo e mundo mediterrâneo à época de Felipe II, cuja primeira edição data de 1949 - até os derradeiros dias de sua vida - como se observa em um seminário realizado em Chateauvallon em sua homenagem, em $1985^{6}$-, ele ratifica a necessidade do aporte geográfico no entendimento da História e na estruturação de sua reflexão.

Nascido em 1902 numa pequena vila na fronteira franco-alemã, Braudel foi um homem que fez do mundo seu laboratório de pesquisas e da História sua grande dedicação. Professor na Argélia nos anos 20 e 30, um dos fundadores da Faculdade de Filosofia, Letras e Ciências Humanas da USP no final da década de 30 no Brasil, cativo dos alemães durante a Segunda Guerra Mundial, eleito para o prestigiado Collège de France em 1950, nome maior da historiografia dos Annales na segunda geração, responsável direto pela fundação da Maison de Sciences de l'Homme em 1963, inúmeros títulos de doutor honoris causa no currículo... São inúmeros os trabalhos publicados e as participações institucionais levadas adiante por este historiador, considerado pelo mexicano Aguirre Rojas como o mais importante do século XX (ROJAS, 2000). Enfim, estudá-lo não parece ser tarefa fácil: embora exista um razoável corpo de trabalhos sobre Braudel e sua obra (AYMARD, 1993; PARIS, 1999; CLAVAL, 1980; GRATALOUP, 2003; DAIX, 1999; ROJAS, 2000; LOPES, 2003; GEMELLI, 1995; LAI, 2004), sua biografia intelectual ainda está por ser escrita ${ }^{7}$ (cf. ROJAS, 2003).

Diante da extensão temporal e de conteúdo abarcados pelo nosso investigado, que abre várias possibilidades de investigação, seguiremos o roteiro de seus três principais escritos: o já citado Mediterrâneo e mundo mediterrâneo à época de Felipe II, que possui a primeira edição original em francês datada de 1949 e que em 1966 terá uma nova edição alterada pelo próprio autor; a trilogia Civilização

\footnotetext{
"Seminário este que tornou-se um pequeno livro, intitulado Uma lição de História de Fernand Braudel, onde ele responde e comenta perguntas dos mais variados especialistas em torno de sua multiforme obra (BRAUDEL, 1989c).

${ }^{7}$ Ainda mais dentro de um campo - a Geografia - que não possui uma tradição de trabalhos de natureza "historiográfica". E aqui as aspas são necessárias para recordar o fato de que não existe, entre os geógrafos, um vocábulo preciso que defina os estudos dedicados ao pensamento geográfico, tal como historiografia define a história da história - o que, para o geógrafo argentino Marcelo Escolar, é um traço significativo de um campo do saber essencialmente empirista e distante da teoria (ESCOLAR, 1995). Esclarecendo: trata-se, pensando em termos da Disciplina Geografia - que disciplina o discurso onde estou corporativamente inscrito - de um estudo sobre o pensamento geográfico (ainda que não queira ser, sob esta alcunha, encerrado) que toma como objeto o discurso de um historiador.
} 
Material, Economia e Capitalismo: Séculos XV-XVII, cuja publicação inicial é de 1979; e seu derradeiro e inacabado livro, o projeto chamado $A$ Identidade da França, editado no ano de 1986 em três volumes ${ }^{8}$. Certamente que privilegiar as obras acima não significa a exclusão das outras, reveladoras que são das várias faces que integram o pensamento Braudeliano - onde a Geografia sempre se manifesta.

\section{A geografia, a longa duração e a originalidade do Mediterrâneo}

Braudel inovava no tratamento conferido não apenas ao espaço, mas também ao tempo. A escrita da história era focalizada em sua forma narrativa e diplomática, juntamente com o conceito de tempo que a acompanhava: o tempo dos eventos, aquele que dá ênfase aos acontecimentos - a histoire événementielle. Esta é uma História de um tempo breve que sugere uma continuidade e uma seqüência dos fatos, justifica as ações do presente e projeta as sociedades para um futuro cujo progresso era praticamente irreversível. A este conjunto de aspectos, Braudel responderá com a dialética da duração: o trinômio presente-passado-futuro dá lugar a uma articulação entre o tempo curto dos eventos, o tempo intermediário das conjunturas e o tempo longo das estruturas. (REIS, 1994). De acordo com Rojas, esta idéia revolucionará as formas de percepção da temporalidade histórico-social, ao afastar-se de uma História vista simplesmente como um acúmulo de acontecimentos situados dentro de uma única matriz temporal (ROJAS, 2001).

Ao se adotar a longa duração como fundamento, ressaltada a especificidade do tempo histórico frente ao tempo dos físicos e dos filósofos, o resultado é uma História cujo tempo torna-se desacelerado, introduzindo "a abordagem da repetição, da permanência, em um conhecimento antes limitado à irreversibilidade e à mudança. (...) Cria-se uma permanência sobre a qual se articulam mudanças mais ou menos lentas"(REIS, 2000:21). Então, a natureza da mudança histórica, tal como os Annales a admitiam, não estava no evento, no acontecimento rápido e provocador de rupturas - tal como a Revolução Francesa, que Braudel minimizava porque revolução inscreve-se, por excelência, no tempo curto (cf. MORAES \& REGO, 2002), mas sim nas transformações quase imóveis e imperceptíveis ocorridas nas estruturas de longa duração.

\footnotetext{
${ }^{8}$ Estaremos nos valendo aqui das seguintes edições: a edição alterada do Mediterrâneo, cujo tomo primeiro refere-se à $5^{\text {a }}$ reimpressão da edição em espanhol datada de 2002 e, para o tomo segundo, a segunda reimpressão de 1987; para Civilização Material, os três volumes da edição em língua portuguesa publicados no Brasil datam, respectivamente, de 1995, 1996 e 1996; A Identidade da França aparece em português do Brasil em três volumes no ano de 1989.
} 
Assim, o que se entende pela concepção braudeliana de história expressar-seá em algumas das palavras-chave de seu vocabulário, como rotina, cotidiano, continuidade e permanência, que remetem seus seguidores àquilo que thes é mais caro: as estruturas da História. Consideram que a História possui uma cadência, um ritmo, uma temporalidade mais durável e resistente à mudança que os obriga a buscar não no agora e na brevidade dos acontecimentos, mas na longa duração aquilo que a sustenta e a constitui como uma totalidade. Isto não significa, contudo, uma negligência para com o evento, mas sim o reconhècimento de que este deve ser suplantado através de sua estruturação em uma duração mais longa. Em outras palavras, visam a superação do evento, posto que ele é relevante apenas na medida em que conduz às estruturas profundas da vida material (LLOYD, 1995).

Este tempo quase imóvel é um tempo geográfico, escreverá o próprio Braudel no prefácio à primeira edição francesa do Mediterrâneo. Nove anos depois, em seu clássico texto teórico-metodológico intitulado História e Ciências Sociais: a Longa Duração, ele continuará a articular a Geografia com as realidades lentas e duradouras, admitindo as sociedades como prisioneiras dos "quadros" e das "coerções" dadas pelos climas e pelas vegetações, destacando a fixidez das civilizações em determinados espaços e a permanência de certas rotas e tráficos na constituição das cidades (BRAUDEL, 1992:50).

Não é este o caso do Mediterrâneo? Um espaço tornado objeto histórico e, assim sendo, sujeito à análise temporal em sua plenitude. Dos climas, das paisagens, das ilhas e do relevo, casados com o homem em suas atividades mais simples (como a subsistência), passando pelas mais complexas (o mar como meio de ligação econômica e palco de disputas políticas, p.ex.); com Felipe II desalojado do lugar central consagrado aos "grandes nomes" pela História tradicional, trata-se de uma completa inovação no campo da História. Com quase quinhentas páginas, a primeira parte - "a mais forte e a mais original" (POMIAN, 1978) - denomina-se $A$ Influência do Meio Ambiente, influência esta que resultará na construção de uma história lenta e que demora a passar, explicitando assim uma complexa interação homem-natureza-espaço que visava ir além das recorrentes introduções geográficas à História. $\mathrm{O}$ espaço mediterrâneo deixa de ser um personagem estático e imutável e passa a ser visto como algo eminentemente histórico, cuja duração Braudel ensejará captar e sublinhar em sua singularidade ${ }^{9}$.

Por acaso estaria Braudel igualando a Geografia ao meio ambiente, atrelando-a às características físico-naturais do Mar Mediterrâneo para capturar a história de longa duração? "Como seu título indica, a primeira parte deste livro está centrada

\footnotetext{
'Un livre qui grandit, escreve Febvre em elogiosa resenha na Revue Historique um ano depois de sua publicação (FEBVRE, 1950). Dentre outros aspectos proeminentes, o Mediterrânẹo inspiraria a realização de trabalhos de natureza semelhante, tais como os de Pierre e Huguette Chaunu sobre o Pacífico e o Atlântico e o de Fréderic Mauro também sobre este último (cf. CARDOSO, 1999).
} 
em torno da geografia". Mas é interessante perceber que ele sublinha o fato de que não se trata somente de Geografia ou, pelo menos, trata-se "de uma geografia muito sui generis, atenta especialmente no que concerne aos fatores humanos". E vai além, apontando a tentativa de criação de uma "espécie particular de história". Aperfeiçoando os contornos de um casamento iniciado pelos primeiros Annales, Braudel vai além daquilo que seus precursores haviam concebido. Com ele, "a geografia deixa de ser um fim em si para converter-se em um meio, ajudando a recriar as mais lentas das realidades estruturais, a ver tudo em uma perspectiva segundo o ponto de vista da duração mais larga" e "a descobrir o movimento quase imperceptível da história" (BRAUDEL, 2002:27).

Mas, afinal, quais são as intenções de Braudel ao colocar a questão sobre a influência do meio ambiente na História? Em primeiro lugar, seria incoerente escrever a história do Mediterrâneo negligenciando a dimensão ambiental, já que ela é constitutiva do objeto que se queria historicizar. Em segundo, de acordo com a pretensão de escrever uma História total, tratava-se não somente de analisar a economia, a política e a sociedade, mas ampliar o campo de atuação da História sublinhando a indissociabilidade do homem com seu entorno e reconhecendo os obstáculos intransponíveis colocados pela natureza à ação humana, as diferentes formas com que as civilizações se adaptavam ao meio e o adaptavam, as mudanças provocadas na paisagem, etc. Por fim, ao lermos o Mediterrâneo, fica evidente a questão da natureza ou, para utilizar uma noção importante e precisa da época, o papel central do meio geográfico na constituição da história das civilizações. Esta "dialética" homem-meio conduziu Braudel a perceber a história como algo durável, estável, sólido, com as atividades humanas engastadas e dependentes de seus respectivos ambientes. Verdadeiramente, o espaço geográfico é algo hostil, no qual as sociedades travam suas lutas pela sobrevivência, seja contra o clima, seja contra a distância. Suas histórias são construidas a partir da relação com o espaço, relação esta que se desenvolve no domínio da longa duração. Assim, esta nova temporalidade desenha-se como o resultado de uma via de mão dupla: das condições efetivas colocadas pelo meio às sociedades e das respostas dadas por estas ao ambiente que as envolve. Esboçada desta forma, uma concepção singular de História resolvia, conjugando o espaço e o tempo dialeticamente, o problema de apreensão simultânea das mudanças e das permanências.

A influência da Escola Francesa de Geografia está presente em todos os momentos da parte inicial do Mediterrâneo, embora diminua sensivelmente em "Destinos Coletivos e Movimentos de Conjunto", e praticamente desapareça em "Os Acontecimentos, a Política e os Homens", terceira e última parte da obra. Redigido em suas grandes linhas desde 1939, o diálogo de Braudel não se resume ao nome de Vidal de La Blache e engloba também os geógrafos Albert Demangeon (professor de Braudel na Sorbonne), Andre Siegfried, Jules Sion, Pierre Deffontaines, Pierre Monbeig, Emmanuel De Martonne, Jean Brunhes, Max. Sorre, Raoul Blanchard, Pierre Gourou, Pierre George, Maurice Le Lannou e Xavier De Planhol. 
Diante desta gama de autores, o que está em voga é, em termos gerais, a concepção de que o meio geográfico admite um conjunto de possibilidades de realização para a atuação humana, concepção esta que se distancia do que Febvre denominou como determinismo geográfico, atribuído ao geógrafo Friedrich Ratzel a fim de, entre outras questões, justificar o expansionismo territorial germânico (FEBVRE, 1991). Portanto, sendo a Geografia Vidaliana a grande referência a ser seguida, sobretudo após a "pregação" de Febvre, tudo levaria a crer que todo e qualquer tipo de determinismo seria inadequado aos historiadores dos Annales.

Não é o que parece a Braudel. Ao interrogar-se acerca das mudanças climáticas desde o século XVI, deixa bem claro que "ninguém crê hoje em dia na imutabilidade dos elementos da Geografia Física" (BRAUDEL, 2002:357). Ainda assim, mais adiante ele irá declarar que "Através das variações do clima, uma vontade alheia ao homem se afirma e reclama a parte que o corresponde em nossas explicações, inclusive nas mais cotidianas. Ninguém põe hoje em dúvida a importância destas variações" (2002:360).

O que significa, então, a influência do meio ambiente sobre a história? Um peso ora esmagador, ora contornável, mas sempre algo do qual as sociedades não podem escapar. Elas acabam acompanhando o andamento das estações, os humores do clima, as dificuldades impostas pelo sítio... A Geografia, tal como concebida por Braudel, impõe parcialmente um ritmo, um movimento, uma cadência, com os quais a história humana necessariamente termina por se adaptar. Muito mais do que um quadro fixo e imóvel, o espaço geográfico representa um personagem histórico e uma estrutura integrante do cotidiano.

Comentando um documento do século XVI, dirá Braudel que a frota turca atacava rapidamente em virtude das "tempranas calmas do mar Egeu. Isto era importante em uma época em que o ritmo das estações influía no ritmo da guerra" (2002:179). Em uma outra passagem, reconhece as dificuldades da navegação durante o inverno, tais como o tempo de viagem, a escassez comercial, os freqüentes naufrágios, etc, tanto no século XIX quanto no XVI: "Estamos falando do ano 1806, quando as galeras praticamente haviam desaparecido do Ocidente; sem embargo, para as que ainda ficavam em Malta ou no Oriente subsiste o mesmo determinismo geográfico da época de Soliman, o Magnífico" (2002:331, grifo nosso).

O francês François Dosse é um dos poucos historiadores críticos da aproximação com a Geografia efetuada pelos Annales. Segundo ele, a forma como o diálogo foi orientado trouxe consequências negativas para a ciência geográfica, tais como o afastamento em relação aos sociólogos, uma condição de subordinação junto à História e a atribuição de um caráter marcadamente empirista (DOSSE, 2004). No tocante a Braudel, ele é enfático: a utilização de raciocínios espaciais aparece muitas vezes como determinismo absoluto, ocorrendo em seus três principais livros de várias maneiras, ora no tocante ao tamanho do território, ora em termos de variações climáticas ou mesmo utilizando metáforas organicistas (DOSSE, 1992). Por sua vez, o mexicano Aguirre Rojas é extremamente favorável à abordagem 
geo-histórica braudeliana, destacando o fato de que a tomada do Mediterrâneo como objeto de estudos é uma novidade singular que impõe a renovação da operação historiográfica (ROJAS, 2003). Além disso, admite em Braudel um determinismo horizontal das estruturas de longa duração, o que não quer dizer a adoção de um raciocínio causal, apriorístico ou hierárquico na explicação dos fenômenos históricos (ROJAS, 2003a: 70-74). Diante deste quadro, o que diria Lucien Febvre?

Por um momento, deixemos de um lado as polêmicas ao redor do determinismo na concepção braudeliana de História, para nos concentrarmos mais de perto no que a Escola Francesa de Geografia ofereceu como arsenal conceitual e metodológico para a escrita do Mediterrâneo. A seguirmos o detalhado trabalho da geógrafa irlandesa Anne Buttimer, o centro da reflexão Vidaliana está focalizado na Geografia da Civilização, cujos três conceitos-chave são: genre de vie, milieu e circulation (gêneros de vida, meio/ambiente e circulação), com destaque para o primeiro, "integrador do lugar, do sustento e da organização social na vida cotidiana de um determinado grupo" (BUTTIMER, 1980:69). Sob a pena do geógrafo brasileiro Paulo César Gomes, o pensamento Vidaliano se estrutura a partir de quatro idéias: organismo, meio, ação humana e gêneros de vida, esta última definida:

(...) como a forma específica que cada grupo desenvolve, sua maneira de ser e de viver. Eles compõem um conjunto particular de atitudes que tiram sua significação do interior do próprio grupo, seja pela maneira de se vestir, de falar, de habitar, em suma, por sua maneira de ser. Ao mesmo tempo, os gêneros de vida revelam os meios desenvolvidos por uma coletividade para sua sobrevivência, superando, em diversos niveis, o desafio da natureza em um meio concreto e imediato. Eles são fruto de escolhas humanas frente ao meio ambiente, escolhas das quais a sucessão conduzirá ou não a uma progressão mais ou menos rápida, a uma conquista mais ou menos eficaz. Os gêneros de vida atuais são, portanto, resultados contingentes dos gêneros de vida anteriores, ao longo de uma cadeia contínua, regida não por uma idéia de necessidade, mas somente de possibilidade. (GOMES, 1996:205).

Para aqueles que já tiveram a oportunidade de ler "A Influência do Meio Ambiente", a primeira parte do Mediterrâneo, a definição anterior não estaria adequada se fosse tomada como sua síntese? Nela estão presentes algumas palavras fundamentais que integram a redação braudeliana, como meio, sobrevivência, natureza e possibilidade, bem como as noções de tempo e de História. E acaso não poderíamos interpretar "A Influência do Meio Ambiente" como a reconstrução dos processos históricos de adaptação das sociedades e civilizações ao espaço geográfico característico do Mediterrâneo? Ao abrir o Mediterrâneo, Braudel historicizava um espaço, deslocando a hegemonia da História Política e dialogando com os principais nomes da Geografia francesa. Enfatizava, p.ex., as montanhas 
como refúgios de bruxos e feiticeiras e fonte de recursos e as planícies como meio propício às populações urbanas; revelava as diferenças nos trajes entre montanheses e habitantes das vilas e a raridade de matrimônios envolvendo os mesmos (BRAUDEL, 2002:40-57). A vida montanhesa é a primeira história do Mediterrâneo, "uma fábrica de homens para uso alheio; sua vida difusa e pródiga alimenta toda a história do mar", escreveu Braudel repetindo a fórmula de Deffontaines e Brunhes. Para ele, o Mediterrâneo só pode ser compreendido se enquadrado dentro da antítese entre montanhas e planícies (2002:63-66).

Ampliando a escala regional consagrada pela Geografia francesa, percorre inicialmente o Mediterrâneo do século XVI como se quisesse dizer que antes, bem antes de Felipe II, da política, da diplomacia e da economia, a história das sociedades se inicia com suas conexões com o meio (não será por isso que abre seu último livro se perguntando se a Geografia teria inventado a França?). E descobre assim o cultivo das oliveiras, o nomadismo e a transumância, a alternância das estações, a dinâmica dos ventos, as distâncias. Enfim, as imposições da natureza aos movimentos humanos e seus traços grafados nas paisagens como testemunhos de uma história assaz complexa, diversa e heterogênea. Aqui, o historiador loreno parece reproduzir a afirmação vidaliana de que o homem, como fator geográfico, é ativo e passivo ao mesmo tempo (VIDAL DE LA BLACHE, 1954:41). E apreende sobretudo "ciclos mais que seculares", a permanência de determinados fenômenos em uma ampla escala temporal, uma duração específica, morosa, quase imóvel.

Temos observado a extrema lentidão das oscilações, nômades contra transumantes, montanheses contra a gente das planícies ou das cidades. Todos estes movimentos requerem séculos para completar-se. Ainda que uma planicie conduza a uma vida mais ativa, vence suas águas selvagens e organiza caminhos e canais, podem muito bem transcorrer um par de séculos. Igualmente podem passar um ou dois séculos desde o momento em que uma região montanhosa começa a perder suas gentes por emigração até o ponto em que a economia das planícies tenha absorvido todas as pessoas que necessitava. São processos mais que seculares, que somente podem ser abarcados estendendo ao máximo o campo cronológico da observação (BRAUDEL, 2002:131).

Enfim, são inúmeros os exemplos e a argumentação geográfica postas em prática na feitura do Mediterrâneo. Esquematicamente, as ligações de Braudel com a Geografia talvez possam ser divididas em duas frentes: (a) os conhecimentos geográficos institucionalizados, repartidos entre a hegemônica influência da Escola francesa e a não menos importante tradição alemã (da qual falaremos mais adiante); (b) os conhecimentos geográficos empiricizados, resultado de suas vivências em lugares diferentes como Lorena, Paris, Argel, São Paulo e mesmo no cativeiro nazista. A historiadora grega Erato Paris dedicou-se a mapear as referências 
intelectuais mais importantes da época da preparação do livro supracitado, identificando as idéias, os temas principais e as apropriações nele realizadas (PARIS, 1999). O roteiro por ela desenhado permite acompanhar os passos "geográficos"de Braudel e suas respectivas experiências intelectuais, experiências estas que hoje chamaríamos de "des-territorialização" (cf. DELEUZE \& GUATTARI, 1992: 111146, que inclusive citam Braudel e sua geo-história). A trajetória empreendida pelo autor impactará sensivelmente seu olhar sobre o Mediterrâneo (percebido não apenas da Europa, mas também a partir da África e da América) e a formação de uma concepção de História atenta às demandas geográficas.

Não inteiramente, decerto, mas é a este conjunto de aspectos que podemos chamar de geo-história braudeliana.

\section{A geografia, a economia e as escalas na confecção de Civilização Material}

No começo da parte segunda do Mediterrâneo, sobretudo em seu capítulo de abertura "As economias: a medida do século", Braudel declara explicitamente que o espaço é o inimigo número um (BRAUDEL, 2002:473). Encontramos certo parentesco entre esta idéia e o volume I de Civilização Material, Economia e Capitalismo: Séculos $X V$-XVIII, publicado trinta anos após a obra anterior, no também capítulo de abertura "O peso do número". Trata este capítulo de uma geografia diferencial do globo revelada pelos números, onde a diversidade transparece no contraste entre densidade e continentes pouco povoados, entre civilizações de um lado e culturas ainda primitivas do outro (BRAUDEL, 1996:19). O que parece unir estes momentos das obras em tela é a dimensão geográfica da Economia, tópico crucial na concepção braudeliana de história e que atravessa do início ao fim os três volumes de Civilização Material.

Entretanto, antes de nos atermos ao papel da Geografia na constituição da história do capitalismo, pois é assim que observamos a contribuição daquela para os objetivos e propósitos de Braudel em Civilização Material, vejamos um pouco mais do desenho e das originalidades do que Pierre Daix considera a "Obra Magna" de nosso investigado, assim como algumas diferenças e continuidades em relação ao Mediterrâneo.

O esquema tripartite mantém-se presente: "As Estruturas do Cotidiano: o Possível e o Impossível", "Os Jogos das Trocas" e "O Tempo do Mundo" (partes constituintes da obra) representam os três andares de uma arquitetura bastante particular: bem próxima ao chão, uma infra-economia, a informalidade da atividade econômica, a auto-suficiência, as atividades corriqueiras e banais, unidas e cunhadas como vida material ou civilização material. Tal noção expressa parte dos acordos e desacordos de Braudel com a Antropologia estruturalista francesa, sobretudo com as conclusões de Claude Lévi-Strauss, colega na missão francesa fundadora 
da USP na década de 30. Esta relação, porém, não impediu Braudel de rechaçar um Estruturalismo a-histórico e inalterável, que dividia as sociedades em "frias" e "quentes", sociedades sem e com história, inteiramente diferente da história estrutural aberta a mudanças preconizada pelo historiador (BRAUDEL, 1992; ROJAS, 2003:62; REIS, 1994: 62-67, REIS, 2000:104-107). O que ficou, contudo, foi uma riquíssima história dos costumes e da cultura das sociedades modernas através das bebidas, das comidas, dos materiais usados na construção das casas, dos móveis e das decorações plurais ao redor do mundo, das roupas e estilos impostos pela moda, etc.

Mas a civilização material sustenta-se e reproduz-se por intermédio da transformação de seu habitat, organizando-o e reorganizando-o de acordo com a habilidade e o maior ou menor domínio das técnicas então disponíveis a seu alcance. Em outras palavras, este conceito complementa o papel da base geo-histórica dos processos civilizatórios (ROJAS, 2003:94). É assim que o capítulo "O pão de cada dia", tratando dos cultivos (e da comercialização desigual) de trigo, arroz, milho, das revoluções alimentares do XVIII e da agricultura de comunidades primitivas fora da Europa, é sintomaticamente descritivo, paisagístico e focado na relação homem-meio, assemelhando-se bastante aos trabalhos da Geografia Clássica na qual Braudel foi educado. Não é por outra razão que são feitas aqui menções a Pierre Gourou, Max Sorre, Étienne Juillard, Pierre Deffontaines, Max Derruau, Humboldt e Vidal, aparecendo até mesmo o nome do geógrafo norte-americano Carl Sauer.

"Claro que a água é o grande problema. Ela pode submergir as plantas: no Sião e no Camboja foi preciso utilizar a flexibilidade inaudita do arroz flutuante, capaz de lançar caules com 9 ou 10 metros de comprimento para resistir aos enormes desníveis dos lençóis de água. A ceifa faz-se de barco, cortando as espigas e abandonando a palha que por vezes tem um comprimento incrível. Outra dificuldade: trazer, depois escoar a água. Trazê-la por condutas de bambu que vão buscar a água às fontes altas; colhê-la, como se faz na planície do Ganges e muitas vezes na China, em poços; conduzi-la, como no Ceilão, para grandes reservatórios, os tanks, mas os tanques coletores de água estão quase sempre num nível baixo, por vezes profundamente cavados no solo. (...) Claro que o sistema escolhido depende das condições locais. Quando não há método de irrigação possível, o aterro do arrozal serve para reter a água da chuva que basta para alimentar uma grande parte das culturas de planície, na Ásia das monções" (BRAUDEL, 1996:130).

O homem, a natureza e a técnica, dispostos em seus liames históricos e geográficos: acaso a passagem anterior não nos conduz a um vagaroso avanço na luta cotidiana do homem contra a natureza e contra ele mesmo? Não seria o Braudel Vidaliano lendo a Geografia como uma herança histórica estrutural? Não poderíamos decodificar o possivel e o impossivel complementares ao título "As Estruturas do Cotidiano" como a perspectiva da Geografia tanto do ponto de vista das determinações quanto do ponto de vista das possibilidades? 
No volume seguinte, "Os Jogos das Trocas" ${ }^{10}$, estamos no andar do meio do edifício braudeliano, onde prevalecem a produção e a troca dentro dos mercados nacionais, nas feiras, bancas, lojas, etc, tornando mais complexa a dinâmica econômica quando comparada aos esforços diários de subsistência materializado pelas civilizações. Aqui, o comércio entra em cena e, aos poucos, se assenhora dela, expandindo os limites dos espaços conhecidos e desconhecidos dentro e fora da Europa. Outro efeito deste processo é a ampliação das regras de mercado com a criação de bolsas de valores, letras de câmbio e companhias de comércio, embora coexistam com mascates, feiras urbanas onde se encontra de tudo um pouco e a preponderância do feudalismo na Europa. Inevitavelmente, a lenta e desigual penetração capitalista vai engendrando o que, nos dias atuais, é incrivelmente comum: a escala mundo dos negócios, dos costumes, do trabalho, da vida banal enfim. O mundo como o lar, como a casa que habitamos todos os dias e da qual saímos e entramos, de forma quase inconsciente. $E$ isto bem antes da imponente Revolução Industrial, minimizada por Braudel em função de seu esquema metodológico da longa duração, que incorpora o evento no âmbito da estrutura.

$O$ fato é que as trocas e seus jogos pressupõem a vitória - ainda que momentânea, dadas as lutas pela sua manutenção - sobre os espaços, estratégias de controle e domínio, confecção de cartas, atuação articulada em diversas escalas, etc. Escrevendo em pleno século XX, Braudel se dá conta de que o processo de expansão do capital a uma escala global tem como uma de suas prioridades históricas a conquista do espaço, "Pois qualquer troca ocupa um espaço e nenhum espaço é neutro, isto é, não modificado ou não organizado pelo homem". (BRAUDEL, 1996a:156). Daí seu esforço de desenhar uma Geografia retrospectiva dos mercados, a fim de avaliar com maior nitidez o desenvolvimento das trocas, do comércio, da economia como um todo. Mas o tópico sobressalente do livro em voga que o aproxima da Geografia consiste no conceito de rede, onipresente nos dias atuais e amplamente empregado por Braudel há décadas atrás. Formando redes políticas, sociais, econômicas ou técnicas, a empreitada capitalista e a preeminência européia difundem-se e deslocam-se com seus tentáculos cirurgicamente interligados. "Centralizado em Lisboa, estendido às duas margens do Atlântico, africana e americana, ligado ao Pacífico e ao Extremo-Oriente, o sistema português é uma imensa rede que se expande pelo Novo Mundo em dez ou vinte anos. Esta viva expansão é forçosamente um fato de importância internacional" (1996 a: 137, grifo nosso).

\footnotetext{
1" Dedicado a Pierre Gourou, considerado por Braudel em La Dynamique du Capitalisme "o maior dos geógrafos franceses" (BRAUDEL, 1985:18). Gourou ainda escreverá o artigo "História e Geografia" na coletânea Europa dirigida por Braudel (GOUROU, 1996), e tudo indica que no decorrer da redação de $A$ Identidade da França (conforme as notas indicadas no final do volume I) eles trocaram correspondências (BRAUDEL, 1989:347-351).
} 
Aqui, ao mergulhar nos temas próprios da História Econômica, os geógrafos franceses saem um pouco de cena para dar lugar à tradição alemã. A documentada pesquisa de Paris desvenda que, enquanto esteve prisioneiro do nazismo, Braudel teve contanto com obras metodológicas e estudos sobre o Mediterrâneo, a Geografia e a História escritas pelos alemães, e chegou a ser nomeado em 1941 reitor da Universidade do Campo, dando seus cursos na Universidade de Oflag de Mayence. Neste mesmo ano, em carta enviada a Febvre, conta que na França a Geografia Humana e a Economia Política estavam excessivamente defasadas, e interessa-se por revistas de História, História Econômica e Social e Geografia contendo reflexões dos geógrafos Alfred Hettner e, sobretudo, Alfred Philippson, bem como os historiadores geógrafos Sternberger, Gehler, Fritsche, Carus e Okel (PARIS, 1999:281-295).

Nesse sentido, em um artigo profundamente esclarecedor a respeito de como Braudel concebe e se apropria dos conhecimentos geográficos institucionalizados, ele faz questão de demarcar as dessemelhanças entre franceses e alemães: de um lado, a já aludida relação homem-meio e, de outro, o trinômio espaço, sociedade $\mathrm{e}$ economia (raum, gesellschaft e wirtschaft). Não é demais recordar que, tendo $A$ Terra e a Evolução Humana como fundamento a ser seguido, a reprovação aos geopolíticos ratzelianos de "livros e afirmações simples", que "nunca acreditaram no possibilismo", é indisfarçável. Todavia, a partir do conceito de economia-mundo (weltwirstchaften), Braudel explorará, como poucos, os férteis vínculos admitidos pelo trinômio em jogo: "Tenho necessidade de dizer que a economia modela o social e o espaço, que o espaço comanda a economia e o social, que o social a seu turno comanda as duas outras realidades". (BRAUDEL, 1997:89). Talvez agora fique mais visivel porque o interesse nas redes, "que se completam, associam-se, substituem-se, afrontam-se", formando circuitos e desenhando um sistema (BRAUDEL, 1996a:142). E, como não poderia deixar de ser, as cidades, onde historiadores e geógrafos sempre hão de se encontrar. Aqui a marca alemã também se faz notar, em particular a teoria locacional de Von Thünen e seu conteúdo acerca da centralidade, hinterlândia e hierarquias espaciais em termos de povoamento, distribuição e funcionamento das redes de atividades econômicas. Cabe acrescentar que o autor já fora citado também por Braudel no tocante à organização do espaço rural no Mediterrâneo (BRAUDEL, 1989:203-217; BRAUDEL, 2002:77; BRAUDEL, 1996a:161).

O que permanece em "Os Jogos das Trocas" não é uma explicação espacial inerente às origens do capital e do capitalismo? Em um mundo que vive, passo a passo, processos de desterritorialização e reterritorialização, a circulação e o espaço por eles ocupado assumem um lugar fundamental no singular esquema explicativo braudeliano. A interação entre povos, culturas e produtos passa por uma ligação entre as escalas locais, regionais, nacionais, criando as condições para o despontardo mercado mundial. Guardadas as devidas proporções, não haveria uma 
intersecção na década de setenta entre a exposição braudeliana, a tese lefebvriana de que a reprodução do capitalismo é dada a partir da produção do espaço e a reflexão lacosteana do saber pensar o espaço para nele combater? (LACOSTE, 1988; LEFEBVRE, 1974).

Campo de possibilidades aberto, chegamos ao último volume da trilogia, o "Tempo do Mundo", que também poderia chamar-se "Os espaços do mundo". Tempo do espaço, tempo de uma escala, história de uma geografia. Mas também espaço do tempo, escala de um tempo, geografia de uma história, porque o pensamento de Fernand Braudel está longe de ser uma via de mão única. Das Cidades-Estado italianas, "antigas economias de dominação urbana" como Gênova e Veneza, ao surgimento de uma nova e poderosa configuração espacial, o Estado Territorial Moderno; das alternâncias de hegemonia no decorrer do percurso capitalista, bem como a formação dos mercados nacionais e suas fronteiras; da construção das Américas enquanto periferia do sistema-mundo às características políticas e econômicas da África, Rússia, Império Turco e Extremo-Oriente. O resultado é "a apreensão global tanto da economia quanto da sociedade; articulações de uma e de outra com a política; restabelecimento das conexões estruturais entre a esfera cultural e seus alicerces sócio-econômicos, não mais fixados a priori mas observados em suas transformações concretas" (DAIX, 1999:556).

De maneira especial, este volume "gira" como um looping de montanha-russa; ele é cambiante, vertiginoso, e substancializa o mundo em bases concretas aproveitando-se de tabelas e gráficos, vasta iconografia e representações cartográficas em profusão, devidamente discutidos e cuidadosamente situados na composição da narrativa histórica. É uma imensa e desproporcional viagem econômica concebida pelo mundo moderno que Braudel intenta resgatar, descrever, analisar e comparar, mantendo consigo um companheiro inseparável, elemento de junção entre realidades heterogêneas e superpostas mas que não podem prescindir de uma condição comum e fundante de suas existências: o espaço.

Incorporando "o mundo inteiro numa história só" (MORINEAU, 1989:51), inspirando argumentos de cunho territorial em torno dos ciclos sistêmicos de acumulação de capital (ARRIGHI, 1996:IX-XI) e autorizando uma aproximação com a crítica histórica legada por Marx (ROJAS, 2000:79-135), Braudel lança as bases para um diálogo fecundo entre a História e a Geografia. Poucos geógrafos não se orgulhariam de ter escrito "O Tempo do Mundo". Sobre isto, Claval é taxativo: uma das grandes idéias do historiador reside na constatação de que o "lugar e a organização espacial jogam um papel essencial na vida política e econômica". Seguindo raciocínio análogo, seria muito proveitoso por parte dos geógrafos a leitura do texto, pois "mesmo falando sobre as bases materiais - e espaciais - das civilizações, ou mostrando que o controle das redes de transporte e comunicações era a origem dos lucros, ele fala sobre relação entre espaços políticos e econômicos" (CLAVAL, 1980:9-10). Pois por mais que a Geografia queira ser vista como uma 
superciência capaz de realizar a síntese das ciências de análise (MOREIRA, 1984), tenha eleito como palco de estudos os fenômenos ocorridos na superfície terrestre e seja herdeira das cosmografias (GOMES, 1997), é a História à la Braudel que consegue explorar e materializar uma escala mundial lato sensu.

Leiamos um trecho do volume ora em debate. Como parece ser de praxe, Braudel inicia com uma idéia geográfica: "O espaço, fonte de explicação, põe em causa ao mesmo tempo todas as realidades da história, todas as partes envolvidas da extensão: os Estados, as sociedades, as culturas, as economias... E conforme escolhamos um ou outro destes conjuntos, modificar-se-ão o significado e o papel do espaço. Mas não inteiramente" (BRAUDEL, 1996b:12).

Parágrafo sugestivo sobre o poder de sedução exercido pelo espaço, cuja espessura é revestida de historicidade e cujo domínio amplia o processo histórico em si mesmo. Seus sentidos e suas representações não se encerram no meio ambiente, tal como acontece na maior parte do Mediterrâneo. O espaço é, dependendo da perspectiva adotada, político, social, simbólico e econômico, variando em seus sentidos e em suas funções. "Mas não inteiramente" pois, de qualquer forma e em qualquer variável analisada, o espaço sempre constará como uma problemática a ser levada em conta. Independente do objeto, ele é uma estrutura, ou seja, um item de resistência às mudanças rápidas, a matéria-prima imprescindível que ocupa todos os andares de uma história edificada em ritmo secular.

Destarte, na esteira do legado deixado pelos primeiros Annales e acrescido dos avanços metodológicos perpetrados por Braudel, não há como perder de vista que a ampliação da escala espacial é fator determinante na ampliação dos próprios domínios da História. Embora o Mediterrâneo possa situar-se tradicionalmente nos marcos de um enfoque regional, ele não é a história de uma região conforme Bloch e Febvre haviam se empenhado em fazê-la, mas sim a história de um mundo em si, de uma economia-mundo sem fronteira e cartografia definidas de maneira habitual. Civilização Material, por sua vez, encaminha sua argumentação em direção aos territórios nacionais que se sucedem alternadamente à frente do navio capitalista, mas isto não significa que ele seja uma história dos Estados-Nação e sim um painel de como estes viabilizaram ao longo dos séculos a escala-mundo como cenário priviliegiado de suas operações. É uma das façanhas de Braudel e um traço "dialético": as escalas devem ser superadas porque a história humana não possui limites, mas ao mesmo tempo ela não existe sem os limites impostos pelos espaço.

\section{A identidade da Geo-História em A Identidade da França}

A problemática acima referida também está no centro das atenções na obra $A$ Identidade da França. Concentraremo-nos no volume de abertura "Espaço $\mathrm{e}$ 
História" ", valioso estudo da formação territorial francesa atrelada ao continente europeu sob a égide da longa duração - ultrapassando os vínculos fixados muitas vezes de maneira naturalizada entre Estado Nacional e território.

Para os geógrafos, o sentimento de privilégio é duplo: primeiro, porque Braudel se pergunta se a Geografia teria inventado a França, mostrando uma ousadia que os geógrafos na década de 1980 (quando o livro foi redigido) dificilmente revelariam; segundo, devido ao reiterado diálogo com a Escola Francesa de Geografia: Vidal, Demangeon, Sorre, Deffontaines, Gallois, De Martonne, Siegfried, Vallaux, mas também Le Lannou, Gourou, Dulaure, Allix, Rochefort, Bonnaud, Estienne. Ao conhecimento geográfico, mais uma vez, é conferida vital importância.

É bem conhecido o fato da História Política ter sido deslocada pelos Annales da posição central que mantinha dentro da Escola Metódica, sendo reabilitada na França apenas por volta de 1965 (RÉMOND, 1996); no entanto, em um campo de conhecimento que só adquire autonomia no século XIX a partir de uma estreita trama com o Estado, dificilmente a preocupação com a nação, com o território e com a política não seriam evidenciadas em algum instante.

E podemos notar isto claramente mesmo nos primeiros Annales: Bloch escrevendo a História do tempo presente no bojo da derrota francesa em 1940 (BLOCH, 2000); e Febvre refletindo sobre o caráter europeu do Rio Reno, alvo de disputas territoriais entre a França e a Alemanha, sobre as Revoluções e o problema das nacionalidades na Europa nos anos de 1944 e 1945 e, por fim, acerca da honra e da pátria entre 1945 e 1947, num período diretamente impactado pela Segunda Guerra Mundial (FEBVRE \& DEMANGEON, 1935; FEBVRE, 1998, 2004).

Dando continuidade a este legado, desta vez o Braudel dos grandes espaços recortará a escala nacional com o objetivo de discorrer sobre a identidade francesa, num acerto histórico de contas com sua terra natal. Este livro aparece ao público em 1986 quando a Europa vive uma conjuntura marcada por três aspectos entrecruzados: (i) o neoliberalismo como modelo de política econômica a ser adotada, tendo como meta principal a diminuição do papel do Estado Nacional; (ii) o esfacelamento do Socialismo Real e, consequentemente, a incidência de uma série de conflitos nacionalistas na URSS, nos Bálcãs e no Leste Europeu; e (iii) o progressivo desenrolar da Globalização, colocando em xeque as identidades nacionais por todo o mundo. Especificamente, na virada dos nos 80 o debate girava na França em torno do ensino de História, da diluição da memória nacional

\footnotetext{
" Embora os volumes II e III, "Os Homens e as Coisas", também focalizem questões como a expansão geográfica através das Cruzadas, o papel das ferrovias e estradas interligando o território da França, a transição de uma economia camponesa para uma economia urbano-industrial, a imigração estrangeira, etc. (BRAUDEL, 1989a, 1989b).
} 
e da perda dos grandes referenciais, fazendo com que os historiadores se voltassem aos temas e discursos nacionais (DOSSE, 2001; HARTOG, 2003).

Em outras palavras, Braudel está reproduzindo um dos tópicos centrais da metodologia annaliste: a articulação passado-presente. E a Geografia viabiliza e permite a apreensão das múltiplas temporalidades, seja através das permanências grafadas na paisagem ou do espaço como um dado da realidade presente. Afinal, o espaço geográfico é uma "rugosidade", onde antigas formas vão assumindo novas funções no desenrolar do tempo (SANTOS, 1978:138). Porém, para Santos, Braudel teria colonizado a Geografia, vinculando-a quase que exclusivamente ao tempo longo. Mesmo sucinto, ele vai além e diz que a oposição tempo longo-tempo curto perde eficácia em nossos dias, propondo substituí-la pelo par tempo rápido-tempo lento (SANTOS, 2002:266-267).

"Evidentemente, há vários modos de por em questão a geografia. Pode-se utilizála por ela mesma, segundo seus problemas próprios e segundo suas confluências com as outras ciências do homem e com as ciências da natureza. É o que fazem os geógrafos, especialmente atentos para o atual. Mas a geografia, para nós, será sobretudo uma maneira de reler, de ponderar, de reinterpretar o passado da França (...) As paisagens e espaços não são unicamente realidades presentes, mas também e amplamente sobrevivências do passado. Horizontes passados se desenham, se recriam, para nós, por meio dos espetáculos oferecidos: a terra, como nossa pele, está condenada a conservar as marcas das antigas feridas" (BRAUDEL, 1989:25).

Aqui, mesmo diante de um cenário aparentemente novo, observa-se a presença de duas companhias inseparáveis: a longa duração e o espaço geográfico. Escrever a história da França e de sua identidade passa, inequivocamente, pela geografia, ou seja, pelas paisagens, regiões e o território do país, "numa tensão permanente entre o espaço e a história" (AYMARD, 1989:66). Assim sendo, Braudel ratifica um ponto de vista que o acompanhou desde o Mediterrâneo: o peso jogado pelas determinações geográficas no desenvolvimento do processo histórico.

Mesmo diante das objeções suscitadas pelos geógrafos Etienne Juillard e Claude Raffestin em Chateauvallon, que defendem a possibilidade de escapar às imposições do espaço, ele se pronuncia dizendo que este se transforma, mas que quase sempre é o mesmo; o espaço é uma realidade inexorável. E mais: afirma sua paixão por uma Geografia mais antiga, cuja abordagem o distinguia nitidamente da geração que o questionava naquele instante, e acusa os geógrafos de desespacializarem a história (BRAUDEL, 1989c:166-170). Aqui, as duas tradições que Febvre havia forjado no início do século XX - para, no mesmo instante, separar -, e que a história do pensamento geográfico ratificou como dicotômicas, são conjugadas quase de forma indistinta. Para o Braudel geógrafo, possibilismo e determinismo caminham lado-a-lado.

Sobre este ponto, para o historiador britânico Perry Anderson a escolha da França como objeto empírico é um reflexo da primazia teórica conferida à Geografia na causação social (ANDERSON, 1996), cujos impactos podem ser sentidos na 
economia, na cultura e na sociedade. Já Rojas aponta que Braudel consegue, ao examinar a base geo-histórica da identidade civilizatória francesa, superar o mito moderno do domínio irrestrito do Homem sobre a natureza, ultrapassando a si mesmo na condução da geo-história (ROJAS, 2003a). O historiador francês Bernard Lepetit, a seu modo, também crê que, tanto em $A$ Identidade da França quanto em Civilização Material, Braudel supera o determinismo com um possibilismo revisitado, produzindo uma rica reflexão sobre as escalas e as durações (LEPETIT, 1986).

Este é um debate que, por enquanto, deixaremos em aberto. Embora fundamental, há outros elementos que compõem o destacado papel dado à Geografia no livro em tela. Nele, a forma como Braudel recolhe e se apropria da ciência geográfica pode ser vista como uma fusão de duas perspectivas: a primeira fixa-se na relação das sociedades com o meio - majoritária no Mediterrâneo - , ao passo que a segunda recorre aos papéis do espaço no que tange à dimensão econômica da sociedade majoritária em Civilização Material.

É desta forma que encontramos em A Identidade da França tópicos como o solo, o meio ambiente, o ecossistema, as fronteiras e distâncias ("naturais" e "humanas"), o desenho do sítio e a situação das cidades, as desigualdades cidadecampo, a circulação, as redes, as regiões, as escalas... Nesse sentido, podemos ler algo como "A terra, o meio, o meio ambiente, o ecossistema são palavras que designam aquilo que ela [a Geografia] nos aporta, as aproximações que ela nos impõe, e que nos ensinam tanto quanto os mais ricos documentos de arquivos" (BRAUDEL, 1989:26). Igualmente: "Concluí que a organização do espaço é por si só criadora de desigualdade e de hierarquia. Marx via, no conflito cidades-campos, o mais velho exemplo da luta de classes: eis justamente uma visão genial"' (1989:145).

Não viria esta notória simbiose entre espaço e história de sua principal fonte geográfica, esta ambígua disciplina ora física, ora humana, moldada por Vidal de la Blache? Tal leitura não seria tributária de questões epistemológicas mal resolvidas no âmbito da ciência geográfica, tais como a tradição empirista, as indefinições em torno do objeto, as subdivisões em diversos ramos e a amplitude dos temas de estudo?

\section{Conclusões seletivas de uma pesquisa em andamento}

Talvez tenhamos trilhado o caminho oposto ao de Pierre Daix, que se desculpa pelo peso excessivo concedido à Geografia na explicação da trajetória intelectual do historiador Fernand Braudel, admitindo, ainda, que tal ênfase se devia à presença da disciplina na formação dos historiadores de sua geração (DAIX, 1999:15). Tentando reunir argumentos que nos permitam responder como o historiador francês Fernand Braudel apropriou-se do conhecimento geográfico como elemento explicador do processo histórico e saber constituinte da elaboração de uma nova 
prática historiográfica, nos deparamos com algumas questões. No sentido de compreender o significado epistemológico da Geografia no conjunto da concepção braudeliana da História, que é o objeto da pesquisa em curso, apontemos a seguir alguns de seus resultados parciais:

1. Braudel fez questão de insistir na relevância dos fatos geográficos para a pesquisa histórica, caminhando inclusive contra uma trajetória em França de progressivo arrefecimento do diálogo com a Geografia (BOUTRY, 1998);

2. Supera as introduções geográficas descritivas, paisagísticas e "passivas", fazendo com que a Geografia tenha papel "ativo" e condicionante na explicação histórica;

3. Captura a complexidade e a riqueza empírica da história, do movimento de expansão das sociedades, do contra-golpe das civilizações construindo paisagens e transformando o meio ambiente;

4. Dialoga com vários representantes da Escola Francesa de Geografia, como Demangeon, Sorre, Deffontaines e Brunhes, e não somente com Vidal.

5. Também é influenciado pelos geógrafos, historiadores geógrafos e economistas alemães que exploraram a questão espacial fora do modelo francês homem-meio, tais como Hettner e Philippson; Sternberger, Gehler, Fritsche, Carus e Okel; Von Thünen.

6. Assimila a proposta de Geografia expressa em $A$ Terra e a Evolução Humana, embora confira peso expressivo ao determinismo geográfico - em aparente contradição com as conclusões de Febvre;

7. Redimensiona o sentido do termo "localizar", contextualizando historicamente o sítio e a situação geográfico para além do esquematismo cartográfico de base cartesiana.

Acreditamos que a Geografia foi uma das janelas interpretativas para que Braudel partisse (o meio ambiente no Mediterrâneo), desenvolvesse (as escalas do mundo capitalista em Civilização Material) e chegasse mesmo a algumas conclusões ousadas (a invenção da nação francesa pela Geografia em $A$ Identidade da França). Com base em tal suposição, sustentamos que a Geografia constitui um caminho privilegiado de análise da obra braudeliana como um todo.

EPISTEMOLOGIAS BRAUDELIANAS: ESPAÇO, TEMPO E SOCIEDADE NA CONSTRUÇÃO DA GEO-HISTÓRIA

Resumo: O pensamento do historiador francês Fernand Braudel admite várias interpretações e possui determinadas influências. Uma delas diz respeito à Geografia Humana Vidaliana, aspecto este que foi pouco explorado até aqui pelos seus estudiosos, sejam eles historiadores ou geógrafos. Este artigo, concentrado sobretudo nos livros $O$ 
Mediterrâneo e o mundo mediterrâneo à época de Felipe II (1966); Civilização Material, Economia e Capitalismo: Séculos XV-XVIII (1979); e A Identidade da França (1986) pretende discutir o papel epistemológico da Geografia em sua obra, partindo da hipótese de que esta foi fundamental para o desenvolvimento das inovações que caracterizam sua escrita da história. Ao mesmo tempo, deseja repensar as relações entre a Geografia e a História no decorrer do século XX.

Palavras-Chave: Fernand Braudel, Vidal de la Blache, Annales, Pensamento Geográfico, Historiografia, Geo-história

BRAUDELIAN EPISTEMOLOGIES: SPACE, TIME AND SOCIETY IN THE CONSTRUCTION OF GEO-HISTORY

Abstract: The thought of French Historian Fernand Braudel has several interpretations and different influences. One of them refers to Vidalian Human Geography, neglected by their researchers - both geographers and historians. This article stresses on his three major works (The Mediterranean 1966, Civilization and Capitalism 1979 and Identity of France 1986) and it debates the Geography's epistemological role in his historiography. At the same time, we intend to rethink the relations between Geography and History in the 20th Century.

Keywords: Fernand Braudel, Vidal de la Blache, Annales, Geographical Thinking, Historiography, Geo-History

\section{BIBLIOGRAFIA}

ANDERSON, Perry. 1996. Fernand Braudel e a identidade nacional. In: ANDERSON, Perry. Zona de Compromisso. São Paulo: Unesp.

ARRIGHI, Giovanni. 1996. O Longo Século XX: Dinheiro, Poder e as Origens do Nosso Tempo. Rio de Janeiro/São Paulo: Contraponto/Unesp.

AYMARD, Maurice. 1989. Uma certa paixão pela França, um certa idéia de história. In: LACOSTE, Yves (org.). Ler Braudel. São Paulo: Papirus.

BERDOULAY, Vincent. 1981. La formation de l'école française de géographie. Paris: Éditions du CNRS.

BLOCH, Marc. 2000. L'étrange défaite. Paris: Gallimard.

2001. A terra e seus homens: agricultura e vida rural nos séculos XVII e XVIII. Bauru: Edusc.

BOUTRY, Philippe. 1998. Certezas e Descaminhos da Razão Histórica. In: BOUTIER, Jean, JULIA, Dominique (orgs.). Passados Recompostos: Campos e Canteiros da História. Rio de Janeiro: Editora da UFRJ/Editora da FGV.

BRAUDEL, Fernand. 1987. El Mediterráneo y el mundo mediterráneo em la época de Felipe II. Tomo Segundo. México: Fondo de Cultura Económica. 1992. História e Ciências Sociais: a Longa Duração. In: BRAUDEL, Fernand. Escritos sobre a História. São Paulo: Perspectiva. 
1997. Géohistoire: la société, l'espace et le temps. In: AYALA, Roselyne de, BRAUDEL, Paule (orgs.). Les ambitions de l'histoire. Paris: Éditions de Fallois.

1989. A Identidade da França: o Espaço e a História - Vol. 1. São Paulo: Globo.

1989a A Identidade da França: os Homens e as Coisas - Vol. 2. São Paulo: Globo.

1989b. A Identidade da França: os Homenis e as Coisas - Vol. 3. São Paulo: Globo.

1989c. Uma Lição de História. Rio de Janeiro: Jorge Zahar.

1992. Reflexões sobre a História. São Paulo: Martins Fontes.

1996. Civilização Material, Economia e Capitalismo: séculos XV-XVIII.

Volume 1: As Estruturas do Cotidiano. São Paulo: Martins Fontes.

1996a. Civilização Material, Economia e Capitalismo: séculos XVXVIII. Volume 2: Os Jogos das Trocas. São Paulo: Martins Fontes.

1996b. Civilização Material, Economia e Capitalismo: séculos XVXVIII. Volume 3: O Tempo do Mundo. São Paulo: Martins Fontes.

2002. El Mediterráneo y el mundo mediterráneo em la época de Felipe II. Tomo Primero. México: Fondo de Cultura Económica.

BURKE, Peter. 1997. A Escola dos Annales (1929-1989): a Revolução Francesa da Historiografia. São Paulo: UNESP.

BUTTIMER, Anne. 1980. Sociedad y medio en la tradición geográfica francesa. Barcelona: Oikos-Tau.

CARDOSO, Ciro Flamarion. 2005. Panorama da Historiografia Ocidental (até aproximadamente 1930). In: CARDOSO, Ciro Flamarion. Um historiador fala de teoria e metodologia: ensaios. Bauru: Edusc.

CARVALHO, Marcos de. 1997. Diálogos entre as Ciências Sociais: um legado intelectual de Friedrich Ratzel (1844 - 1904). Biblio 3W. Revista de Geografia y Ciencias Sociales, $\mathrm{n}^{\circ} 34$. Universidade de Barcelona, Departamento de Geografia Humana [http://www.ub.es/geocritic/b3w34.htm].

.1997a. Ratzel: releituras contemporâneas. Uma reabilitação? Biblio $3 W$. Revista de Geografia y Ciencias Sociales, $\mathrm{n}^{\circ} 25,23$ de abril. Universidade de Barcelona, Departamento de Geografia Humana [http://www.ub.es/ geocritic].

CLAVAL, Paul. 1980. Fernand Braudel (1902-1985). In: Geographers: Biobibliographical Studies, volume 5.

DAIX, Pierre. 1999. Fernand Braudel: uma biografia. Rio de Janeiro: Record. DELEUZE, Gilles, GUATTARI, Félix. 1992. O que é a Filosofia? São Paulo: Ed. 34. DEMANGEON, Albert, FEBVRE, Lucien. 1935. Le Rhin: problèmes d'histoire et d'économie. Paris: Armand Colin.

DOSSE, François. 1992. A História em Migalhas: Dos "Annales" à Nova História. Campinas: Editora da Unicamp/Ensaio. 
2001. A identidade nacional como forma organizadora do discurso histórico na França nos séculos XIX e XX. In: DOSSE, François. A História à prova do tempo. Da História em migalhas ao resgate do sentido. São Paulo: Unesp.

2004. História e Ciências Sociais. Bauru: Edusc.

ESCOLAR, Marcelo. 1993. Crítica do Discurso Geográfico. São Paulo: Hucitec. FEBVRE, Lucien. 1950.Un livre qui grandit: La Méditerranée et le monde méditerranéen à l'époque de Philippe II. Revue Historique. Tome CCIII, 74 année.

1970. Philippe II et la Franche-Comté. Étude d'histoire politique, religieuse et sociale. Paris: Flammarion.

. 1991. A Terra e a Evolução Humana. Introdução Geográfica à História. $2^{\mathrm{a}}$ ed. Lisboa: Cosmos.

1998. Honra e Pátria. Rio de Janeiro: Civilização Brasileira.

2004. A Europa: Gênese de uma Civilização. Bauru: Edusc.

FONTANA, Josef. 1998. História: análise do passado e projeto social. Bauru:

EDUSC.

2004. História dos Homens. Bauru: EDUSC.

FOSTER, John Bellamy, WOOD, Ellen Meiksins (orgs.). 1999. Em Defesa da História: Marxismo e Pós-Modernismo. Rio de Janeiro: Jorge Zahar Editor. FOUCAULT, Michel. 1999. As palavras e as coisas. $8^{a}$ ed. São Paulo: Martins Fontes.

GEMELLI, Giuliana. 1995. Fernand Braudel. Paris: Odile Jacob.

GOMES, Paulo César da Costa. 1996. Geografia e Modernidade. Rio de Janeiro: Bertrand Brasil.

1997. Geografia fin-de-siècle: o discurso sobre a ordem espacial do mundo e o fim das ilusões. In: CASTRO, Iná Elias de, CORREA, Roberto Lobato, GOMES, Paulo César (orgs.). Explorações Geográficas: percursos no fim do século. Rio de Janeiro: Bertrand Brasil.

GOUROU, Pierre. 1996. História e Geografia. In: BRAUDEL, Fernand (dir.). A Europa. Lisboa: Terramar.

GRATALOUP, Christian. 2003. Braudel, Fernand (1902-1985). In: LÉVY, Jacques, LUSSAULT, Michel (orgs.). Dictionnaire de la géographie et de l'espace des sociétés. Paris: Belin.

GURIEVITCH, Aaron. 2003. A Sintese Histórica e a Escola dos Anais. São Paulo: Perspectiva.

HARTOG, François. 2003. O Século XIX e a História. O caso Fustel de Coulanges. Rio de Janeiro: Editora da UFRJ.

LACOSTE, Yves. 1988. A Geografia: isso serve, em primeiro lugar, para fazer a guerra. São Paulo: Papirus.

1989. Braudel geógrafo. In: LACOSTE, Yves (org.). Ler Braudel. São Paulo: Papirus.

LAI, Cheng-Chung. 2004. Braudel's historiography reconsidered. Maryland: University Press of America. 
LEFEBVRE, Henri. 1974. La production de l'espace. Paris: Anthropos.

LEPETIT, Bernard. 1986. Espace et histoire. Hommage a Fernand Braudel. Annales ESC. $\mathrm{N}^{\circ} 6$.

LLOYD, Christopher. 1995. As Estruturas da História. Rio de Janeiro: Jorge Zahar.

LOPES, Marcos Antonio (org.). 2003. Fernand Braudel: Tempo e História. Rio de Janeiro: Editora da FGV,

MORAES, José Geraldo Vinci de, REGO, José Márcio. 2002. Conversas com historiadores brasileiros. São Paulo: Editora 34.

MORINEAU, Michel. 1989. Um grande projeto: Civilização Material, Economia e Capitalismo: Séculos XV-XVIII. In: LACOSTE, Yves (org.). Ler Braudel. São Paulo: Papirus.

MOREIRA, Ruy. 1980. O que é Geografia. São Paulo: Brasiliense. MOTA, Carlos Guilherme (org.). 1994. Febvre. São Paulo: Ática.

MOURA, José Francisco de. 2000.Verdade e realidade: o pós-modernismo e a tentativa de destruição da história-disciplina. Phoînix, Rio de Janeiro, $\mathrm{n}^{\circ} 6$.

PARIS, Erato. 1999. La genèse de intellectuelle de l'oeuvre de Fernand Braudel. Athènes: Institute de Recherches Néohelléniques/FNRS.

POMIAN, Krzysztof. 1984. Les rythmes de l'histoire: Fernand Braudel. In: POMIAN, Krzysztof. L'ordre du temps. Paris: Gallimard.

REMOND, René. 1996. Por uma História Política. Rio de Janeiro: Editora UFRJ/ Editora da FGV.

REIS, José Carlos. 1994. Nouvelle histoire e tempo histórico: a contribuição de Febvre, Bloch e Braudel. São Paulo: Ática.

-2000. Escola dos Annales $3 / 4$ a Inovação em História. Rio de Janeiro: Paz e Terra.

ROJAS, Carlos Antonio Aguirre. 2000. Os Annales e a Historiografia Francesa: Tradições Críticas de Bloch a Foucault. Maringá: Eduem.

—. 2001. Tempo, Duração e Civilização: Percursos Braudelianos. São Paulo: Cortez.

- 2003. Fernand Braudel e as Ciências Humanas. Londrina: Eduem.

- 2003a. Braudel, o mundo e o Brasil. São Paulo: Cortez.

SANTOS, Milton. 1978. Por uma Geografia Nova. Da Crítica da Geografia a uma Geografia Crítica. São Paulo: Hucitec/EDUSP.

2002. A Natureza do Espaço. Técnica e Tempo. Razão e Emoção. São Paulo: Edusp.

VIDAL DE LA BLACHE, Paul. 1954. Princípios de Geografia Humana. Lisboa: Cosmos.

VIDAL DE LA BLACHE, Paul. 1994. La France de l'est (Lorraine-Alsace). Paris: La Découverte. 